\title{
Autologous bone marrow transplantation in a dog with lymphoma: a clinical study
}

\author{
Transplante autólogo de medula óssea em um cão com linfoma: ensaio clínico
}

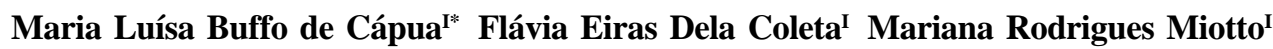 \\ Sabryna Gouveia Calazans ${ }^{I}$ Aline Vieira Godoy' Ana Paula Massae NakageII \\ Carolina Bonduki Sales Lisbão ${ }^{\mathrm{III}}$ Carlos Roberto Daleck $^{\mathrm{IV}}$ \\ Aureo Evangelista Santana ${ }^{\mathrm{IV}}$
}

\section{ABSTRACT}

The objective of this study is to provide the first report of bone marrow transplantation (BMT) in dogs in Brazil. A Rottweiler with cutaneous lymphoma was submitted to a twelve-week Madison-Wisconsin chemotherapy protocol followed by autologous bone marrow transplantation. For this, $10 \mathrm{~mL} \mathrm{~kg}^{-1}$ of bone marrow was collected simultaneously from both iliac crests and cryopreserved in a freezer at $-80^{\circ} \mathrm{C}$. The conditioning step was performed by administering cyclophosphamide by intravenous route at $400 \mathrm{mg} \mathrm{m}^{-2}$. Bone marrow was reinfused after defrosting in a water bath at $37^{\circ} \mathrm{C}$. Bone marrow nucleated cell counts before and after freezing, showed a small relative loss of nucleated cells (35.10 and $31.80 \times 10^{3} \mu L^{-1}$, respectively). Cyclophosphamide induced neutropenia which was reverted by a granulocyte colonystimulating factor (G-CSF) capable of stimulating hematopoetic reconstitution. On the day 360 after transplant the patient was found to be in complete remission. This study indicates that autologous BMT in a dog with lymphoma submitted to myelosuppressive chemotherapy was potentially safe and effective.
\end{abstract}

- NOTE -
Key words: canine, cutaneous lymphoma, autologous bone marrow transplant, chemotherapy.

\section{RESUMO}

Este estudo teve como objetivo descrever o primeiro relato de transplante de medula óssea (TMO) em cães no Brasil. Para tanto, um rottweiller com linfoma cutâneo foi submetido

\begin{abstract}
ao protocolo quimioterápico de Madison-Wisconsin pelo período de 12 semanas, seguido pelo transplante autólogo de medula óssea. Para tanto, $10 \mathrm{~mL} \mathrm{~kg}^{-1}$ de medula óssea foram coletados de ambas as cristas ilíacas do paciente, simultaneamente; sendo o volume final criopreservado em freezer a $-80^{\circ} \mathrm{C}$. A etapa de condicionamento foi realizada com a administração da ciclofosfamida, por via intravenosa, na dose de $400 \mathrm{mg} \mathrm{m}^{-2}$. A reinfusão da medula óssea foi realizada após o descongelamento da bolsa em banho-maria a $37^{\circ} \mathrm{C}$. As contagens de células nucleadas de alíquotas obtidas da bolsa de medula óssea antes do congelamento e após o descongelamento demonstram pequena perda relativa de células nucleadas (35,10 e 31,80 $\times 10^{3} \mu \mathrm{L}^{-1}$, respectivamente). A neutropenia decorrente da ciclofosfamida foi revertida com a administração de um fator estimulador de colônia de granulócitos (G-CSF), que foi capaz de acelerar a reconstituição hematopoética. O paciente encontra-se no dia + 360 pós-transplante em remissão completa da doença. Este trabalho indicou que o TMO autólogo em um cão com linfoma, submetido à quimioterapia mielossupressora, foi potencialmente seguro e efetivo.
\end{abstract}

Palavras-chave: canino, linfoma cutâneo, transplante autólogo de medula óssea, quimioterapia.

Lymphoma is defined as lymphoid neoplasia which primarily affects the lymph nodes or other solid visceral organs such as the liver and spleen (VAIL \& OGILVIE, 1998). It is the most common hematopoetic

'Programa de Pós-graduação, departamento Clínica e Cirugia Veterinária, Faculdade de Ciências Agrárias e Veterinárias (FCAV), Universidade Estadual Paulista (UNESP), Jaboticabal, SP, Brasil. E-mail: marialuisa_capua@yahoo.com.br.*Autor para correspondência.

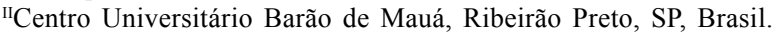

IIIResidente em Anestesiologia Veterinária, FCAV, UNESP, Jaboticabal, SP, Brasil.

${ }^{\mathrm{IV}}$ Departamento Clínica e Cirugia Veterinária, FCAV, UNESP, Jaboticabal, SP, Brasil. 
neoplasia in dogs (MOULTON \& HARVEY, 1990; VAIL \& OGILVIE, 1998; FAN, 2003; DOBSON, 2004), mainly affecting middle-aged or old animals, which make up $80 \%$ of the cases (GREENLEE et al., 1990; MOULTON \& HARVEY, 1990), without sex preference (VAIL \& OGILVIE, 1998). The principal treatment for this disease is antineoplastic chemotherapy. From the different chemotherapy protocols available, response percentages vary from 65 to $96 \%$ and first remission duration is from six to nine months (VONDERHAAR \& MORRISON, 2002). Second remission is generally much shorter than the first one and the survival rate for most dogs treated with conventional protocols varies from ten to twelve months (MORRISON, 2004). The Madison-Wisconsin protocol, a combination of L-asparaginase, vincristine, prednisone, cyclophosphamide, and doxorubicin, has become popular for treating canine lymphoma by providing longer survival times (MORRISON, 2004).

The $\operatorname{dog}$ is a valuable model for hematopoietic stem cell transplantation (HSCT) technology in man (GENGOZIAN, 2000). Most HSCT's in animals were performed in studies for developing new techniques and treatments for diseases analogous to man (GASPER \& THRALL, 2000). Pre-clinical canine studies investigating conditioning regimens of chemotherapy and/or total body irradiation contributed for successful HSCT in human patients (LUPU \& STORB, 2007). Only in the 80's the use of bone marrow transplantation (BMT) as therapeutic intervention for malignant diseases was first seen in veterinary medicine (GENGOZIAN, 2000), of which most were limited to allogeneic experiments. However, at that same time, autologous grafts were given experimentally in dogs with lymphoma, leukemia and solid tumors (LUPU \& STORB, 2007).

Autologous BMT allows increased chemotherapy doses in dogs with lymphoma, resulting in longer remission times (MOORE, 2005). Autologous BMT involves the temporary removal of the patient's own hematopoetic stem cells (HSC), followed by chemically or radiologically induced myelosuppression, and HSC reinfusion (GASPER \& THRALL, 2000). Cyclophosphamide can replace total body irradiation in preparing dogs for autologous or allogeneic BMT (THOMAS \& STORB, 1999).

The objective of this study was to describe the first report of bone marrow transplantation in dogs in Brazil, evaluating the therapeutic potential of autologous BMT in a dog with lymphoma submitted to nonmyeloablative myelosuppressive chemotherapy.
Diagnosis and staging

A three and a half year-old female Rottweiler weighing $34.3 \mathrm{~kg}$ was presented at the Veterinary Oncology Service (VOS) of The Governador Laudo Natel Veterinary Hospital, part of the School of Agrarian and Veterinary Sciences UNESP - Jaboticabal, with weight loss, apathy, hyporexia, and the presence of a skin nodule in the cervical region. Fine needle aspiration cytology of the nodule revealed the presence of abnormal lymphocytes with nuclear and cytoplasmic features of malignancy and supported lymphoma diagnosis. Immunophenotypic analysis of the nodule aspirate was performed by flow cytometry using the following anti-canine monoclonal antibodies: CD45, CD21, CD5, CD4 and CD8 (Serotec). The sample was analysed in a FACSCANTO (Becton Dickinson, San Jose,CA) flow cytometer and revealed a T-cell phenotype. For the disease staging, the patient underwent physical examination, complete blood count (CBC), serum chemistry profile, urinalysis, thoracic radiographs and bone marrow aspiration cytology. Finally, the lymphoma was anatomically classified as cutaneous in clinical stage $\mathrm{Vb}$ (involving bone marrow or peripheral blood and or some non-lymphoid organs with or without stages I to IV with clinical signs of lymphoma)(VAIL \& YOUNG, 2007).

\section{Chemotherapy protocol}

With the owner's authorization, chemotherapy treatment began with the intention to submit the dog to autologous bone marrow transplantation after twelve weeks of the chemotherapy. The animal was submitted to the Madison-Wisconsin chemotherapy protocol, wich is a combination of five drugs: vincristine, cyclophosphamide, L-asparaginase, doxorubicin and prednisone, for 12 weeks (Table 1). After the second chemotherapy session, complete cutaneous nodule remission was verified and there were no relapses during treatment.

With the aim of guaranteeing that the patient would be found in complete remission from the disease, clinical-laboratory and imaging exams were performed on the $13^{\text {th }}$ week. Antibiotics were given from this time ( $2 \mathrm{mg} \mathrm{kg}^{-1}$ sodium celtofur, SID, subcutaneous) up to two weeks post transplantation. A bone marrow sample was taken from the sternum with a 40x12 hypodermic needle and $10 \mathrm{~mL}$ syringe containing EDTA. Cytoscopic samples were then prepared, fixed and stained with May-Grunwald Giemsa, and submitted to a careful and detailed examination to ascertain that bone marrow was free of lymphoma infiltration. The scheme for performing BMT was designed in three stages: Bone Marrow Harvest, High Dose Cyclophosphamide and Bone Marrow Re-infusion performed on day -4, day -2, and day zero (D-4, D-2, and D0), respectively. 
Table 1 - Madison-Wisconsin Chemotherapy Protocol (RODASKI \& De NARDI, 2004).

\begin{tabular}{|c|c|c|c|c|c|}
\hline Weeks & $\begin{array}{l}\text { Vincristine } \\
\left(0.75 \mathrm{mg} \mathrm{m}^{-2}\right)\end{array}$ & $\begin{array}{l}\text { L-asparaginase } \\
\left(400 \mathrm{UI} \mathrm{kg}^{-1}\right)\end{array}$ & $\begin{array}{l}\text { Cyclophosphamide } \\
\left(250 \mathrm{mgm}^{-2}\right)\end{array}$ & $\begin{array}{l}\text { Doxorubicin } \\
\left(30 \mathrm{mg} \mathrm{m}^{-2}\right)\end{array}$ & Prednisone \\
\hline 1 & $\mathrm{X}$ & $\mathrm{X}$ & - & - & $2 \mathrm{mg} \mathrm{kg}^{-1}$ day $^{-1}$ \\
\hline 2 & - & - & $\mathrm{X}$ & - & $1.5 \mathrm{mg} \mathrm{kg}^{-1}$ day $^{-1}$ \\
\hline 3 & $\mathrm{X}$ & - & - & - & $1 \mathrm{mg} \mathrm{kg}^{-1}$ day $^{-1}$ \\
\hline 4 & - & - & - & $\mathrm{X}$ & $0.5 \mathrm{mg} \mathrm{kg}^{-1} \mathrm{day}^{-1}$ \\
\hline 5 & & & Interval & & \\
\hline 6 & $\mathrm{X}$ & - & - & - & - \\
\hline 7 & - & - & $X$ & - & - \\
\hline 8 & $\mathrm{X}$ & - & - & - & - \\
\hline 9 & - & - & - & $\mathrm{X}$ & - \\
\hline 10 & & & Interval & & \\
\hline 11 & $\mathrm{X}$ & - & - & - & - \\
\hline 12 & & & Interval & & \\
\hline
\end{tabular}

\section{Bone marrow harvest}

Bone marrow was harvested by surgical procedure on D-4. For this, the animal received premedication with levomepromazine and meperidine; anaesthesia was induced with propofol, and inhalatory general anaesthesia with isoflurane. Harvesting was performed simultaneously by two correctly apparelled operators, and was achieved due to many aspirations in both iliac crests with Rosenthal needles and $20 \mathrm{~mL}$ syringes. A final volume of $10 \mathrm{~mL} \mathrm{~kg}^{-1}$ animal weight was collected, with each aspiration not exceeding $10 \mathrm{~mL}$ to avoid hemodilution (Figure 1). At the same time as the bone marrow samples were deposited in a $500 \mathrm{~mL}$ glass flask, an assistant added a solution containing sodium heparin Parinex ${ }^{\circledR}$ (Hipolabor), as well as periodically homogenized the content. Once the desired volume of bone marrow was collected, the whole content was

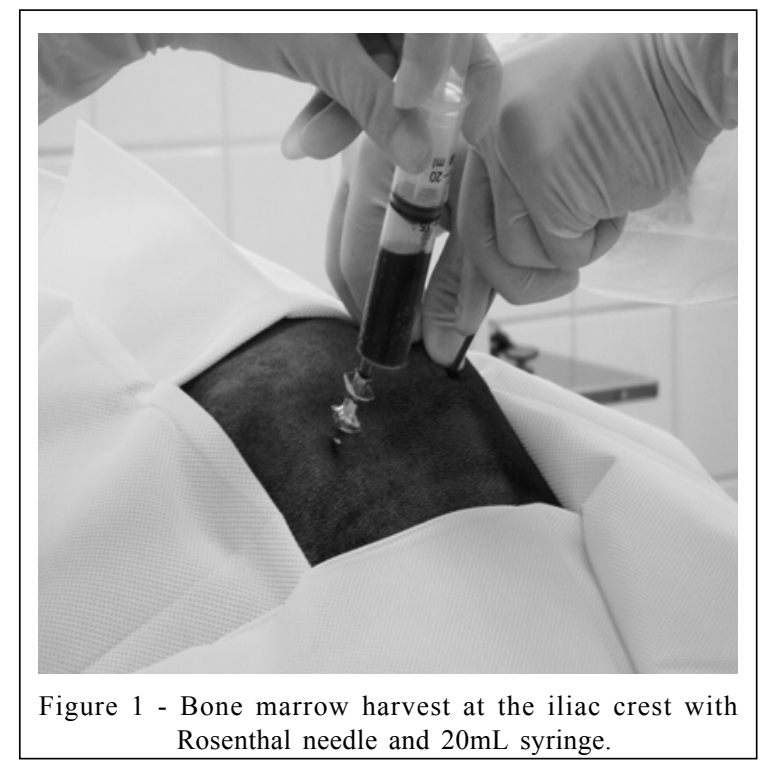

filtered to make sure that fortuitous coagulations and bone splinters were removed. The filtered content was transferred to a blood bag $(500 \mathrm{~mL}$ blood collection bag, CPDA-1, JP Pharmaceutical Industry A.S.), from which anticoagulant had previously been removed. Tramadol chlorate P.O. was administered for two consecutive days to avoid pain at the puncture site. The patient was discharged when recovered from anesthesia.

Bone marrow cryopreservation

After harvest, the bag containing the bone marrow aspirate was then processed in three stages. Firstly, erythrocyte depletion was performed by adding hydroxyethyl starch (HES) (Plasmin ${ }^{\circledR}$ hydroxyethylamide 450/0, 7-6\%, Halexlstar), which accelerates the red cell sedimentation process. The whole process was performed in a laminar flow chamber. The second step consisted of plasma depletion, where the bag of bone marrow was centrifuged for 15 minutes at $3000 \mathrm{rpm}$ and $20^{\circ} \mathrm{C}$, and this was followed by using a plasma extractor to transfer the plasma to another blood bag. The third stage was performed in a laminar flow chamber, under aseptic conditions, the entire content of the blood bag was aspirated with a $60 \mathrm{~mL}$ syringe and transferred to a bag suitable for freezing (BAXTER 500mL Cryocyte Bag for Freezing Blood Components). A mixture was made in the empty bag where the product had been, consisting of $40 \%$ autologous plasma, $40 \%$ RPMI (RPMI 1640 medium - SIGMA), and 20\% DMSO (Dimesol ${ }^{\circledR}$ Marcolab). This procedure was performed in a cube with ice to avoid an exothermic reaction caused by the DMSO which could damage the cells. The bag with the mixture was homogenized and the content was aspirated with a $60 \mathrm{~mL}$ syringe and transferred to a freezing bag. A sample was taken from the referred bag for a total nucleated cell count, which was performed by an automatic cell counter (ABC Vet, HORIBAABX - Sao Paulo, Brazil). 
The bone marrow bag was then manually frozen. Firstly, it was placed in a fridge $\left(4^{\circ} \mathrm{C}\right)$ for one hour, then transferred to a freezer $\left(-4^{\circ} \mathrm{C}\right)$ for two hours, and then finally to another freezer $\left(-80^{\circ} \mathrm{C}\right)$ where it remained until defrosting and infusion four days later.

High dose cyclophosphamide (conditioning)

Conditioning was performed by intravenous administration of $400 \mathrm{mgm}^{-2}$ cyclophosphamide (Cycram ${ }^{\circledR}$ Meizler) on D-2. Intravenous fluid therapy with $0.9 \% \mathrm{NaCl}$ solution (Glicolabor) was given for 30 minutes before and five hours after chemotherapy. Also $160 \mathrm{mg} \mathrm{m}^{-2}$ Mesna (Mitexan ${ }^{\circledR} 100 \mathrm{mg} \mathrm{mL}^{-1}$ Baxter Oncology) was given by intravenous route immediately before cyclophosphamide administration and in the second and fifth hours afterwards.

Bone marrow re-infusion

The infusion stage was performed two days after conditioning, on Day zero (D0). The bone marrow bag was removed from the freezer $\left(-80^{\circ} \mathrm{C}\right)$ and immediately placed in a water bath at $37^{\circ} \mathrm{C}$. Again, a sample was taken from the bag, after thawing, for total nuleated cell count. The animal first received intravenous fluid therapy support of $0.9 \% \mathrm{NaCl}$ (Glicolabor) for 30 minutes followed by infusion of bone marrow solution from the bag. During this procedure, the animal's vital signs were frequently checked. After transplantation, the animal continued to be monitored and received fluid therapy for two hours. Filgrastine ${ }^{\circledR}$ (Blausiegel), a granulocyte colony-stimulating factor (G-CSF), was administered to the patient at $5 \mu \mathrm{g} \mathrm{kg}^{-1}$ day $^{-1}$, subcutaneously, at $\mathrm{D}+3, \mathrm{D}+4, \mathrm{D}+5$, and $\mathrm{D}+6$ to accelerate hematopoietic reconstitution.

\section{Post-treatment monitoring}

Careful physical exams and $\mathrm{CBC}$, accomplished by an automatic cell counter (ABC Vet, HORIBA ABX - Sao Paulo, Brazil), were performed for the patient's post-treatment monitoring. Initial rechecks were made to evaluate hematopoietic recovery from high dose chemotherapy and later rechecks aimed to monitor lymphoma relapses.

According to PATTERSON (1993), bone marrow harvest is a traumatic way of collecting HSC and capable of causing complications to the patient related with anaesthesia and infections. Nevertheless, in this experiment the process was relatively straightforward and quick to perform, obtaining a final volume of $342 \mathrm{~mL}$ of bone marrow. The animal did not show any adverse effects.

There was more difficulty with bone marrow processing stage and this was certainly due to the inexperience of those performing the procedure. However, aliquots were obtained from the bag before freezing and after defrosting to count total nucleated cells. The values obtained were 35.10 and $31.80 \times 10^{3}$ cells $\mu \mathrm{L}^{-1}$ respectively. These results showed that the processing steps were done in an effective way as there was little relative loss of nucleated cells.

For patient's conditioning, in this experiment we used cyclophosphamide, a nitrogen mustard alkylating agent (LANORE \& DELPRAT, 2004; RODASKI \& DE NARDI, 2004) at $400 \mathrm{mg} \mathrm{m}^{-2}$. FRIMBERGER et al. (2006) determined the maximum cyclophosphamide dose to be tolerated by dogs with lymphoma submitted to autologous BMT $(300,400$, and $500 \mathrm{mg} \mathrm{m}^{-2}$ ) with the higher dose having a direct relationship with longer animal survival time.

The haematological and vesicle toxicities, mainly represented by neutropenia and hemorrhagic cystitis, are the main adverse effects related to cyclophosphamide use (LANORE \& DELPRAT, 2004). In this study, neutropenia was reverted by administering Filgrastine ${ }^{\circledR}$ (Blausiegel) at D+3, D+4, $\mathrm{D}+5$, and $\mathrm{D}+6$. This medication was able to accelerate hematopoetic reconstitution (Figure 2). The lowest neutrophil count was on $\mathrm{D}+3\left(432\right.$ cells $\left.\mu \mathrm{L}^{-1}\right)$, when Filgrastine $^{\circledR}$ administration began. Global leukocyte count reached normal levels on D+6 (6100 leukocytes $\mu \mathrm{L}^{-1}$ ), but neutropenia still persisted (2379 neutrophils $\left.\mu \mathrm{L}^{-1}\right)$. Literature reports that ten days are required to recover from haematological toxicity caused by cyclophosphamide (LANORE \& DELPRAT, 2004).

In a study by FRIMBERGER et al. (2006), GCSF was used before bone marrow harvest to facilitate

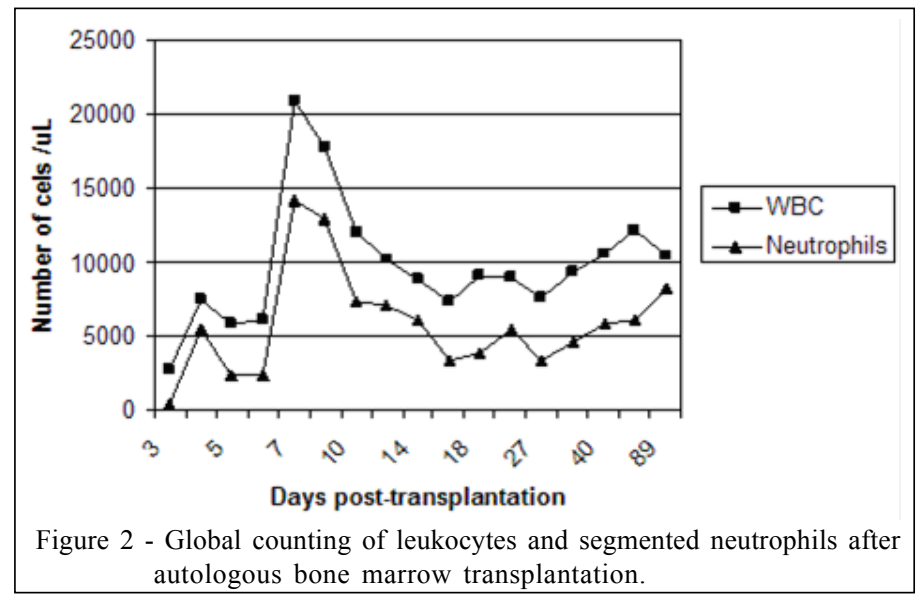

Ciência Rural, v.39, n.2, mar-abr, 2009. 
collection and provide faster grafting. Future studies may clarify questions about the best time to use this cytokine in canine autologous BMT.

Vesicle toxicity was avoided by administering Mesna during the patient's conditioning. Hemorrhagic cystitis is caused by the excretion of acrolein, a metabolite of cyclophosphamide, by the urinary tract, which causes acute local irritation and inflammation accompanied by bleeding (LANORE \& DELPRAT, 2004).

In the initial post-BMT phase, the patient was evaluated for clinical evolution and peripheral blood was taken for haematological evaluation. The animal presented mild apathy and hyporexia on bone marrow infusion (D0) and the following (D+1) day, and did not present fever at any moment. On transplant + 360 days $(\mathrm{D}+360)$, the patient was found to be in complete remission.

The first report in Brazil of BMT in a dog indicated that autologous BMT in a dog with lymphoma submitted to myelosuppressive chemotherapy was potentially safe and effective as the patient was found to be in complete remission on $\mathrm{D}+360$ post transplantation. Complementary studies in dogs with lymphoma are being undertaken by researchers at the Veterinary Clinical Pathology Laboratory and the Veterinary Oncology Service of the FCAV, UNESP, Jaboticabal to confirm the findings of this report. This clinical study may be an important scientific contribution in Brazilian bone marrow transplant for the modern era of cell therapy in Veterinary Medicine.

\section{ACKNOWLEDGMENTS}

The authors are grateful to: FAPESP (Proc. nº. 05/ 01617-8 and 06/03300-1) for financial support; Prof. Dr ${ }^{\mathrm{a}}$. Maria José Soares Mendes Giannini and Luis Gustavo Silva Monnazzi from the Laboratory of Mycology of the Pharmaceutical Science School - São Paulo State University Brazil, for technical support.

\section{ETHICAL AND ANIMAL WELFARE COMMITTEE}

The study was approved by the Ethical and Animal Welfare Committee of the FCAV-UNESP/Jaboticabal. Protocol nº 17265-06.

\section{REFERENCES}

DOBSON, J. Classification of canine lymphoma: a step forward. Veterinary Journal, London, v.167, n.2, p.125-126, 2004.

FAN, T.M. Lymphoma updates. Veterinary Clinics of North America: Small Animal Practice, Philadelphia, v.33, n.3, p.455-471, 2003.

FRIMBERGER, A.E. et al. A combination chemotherapy protocol with dose intensification and autologous bone marrow transplant (VELCAP-HDC) for canine lymphoma. Journal of Veterinary Internal Medicine, Philadelphia, v.20, n.2, p.355-364, 2006.

GASPER, P.W.; THRALL, M.A. Hematopoietic stem cell transplantation. In: FELDMAN, B.F et al. (Eds.). , Schalm's veterinary hematology. Philadelphia: Lippincott Williams \& Wilkins, 2000. p.97-101.

GENGOZIAN, N. Identification and isolation of hematopoietic progenitors. In: FELDMAN, B.F. et al. (Eds.). Schalm's veterinary hematology. Philadelphia: Lippincott Williams \& Wilkins, 2000. p.91-96.

GREENLEE, P.G. et al. Lymphomas in dogs: a morphologic, immunologic, and clinical study. Cancer, Philadephia, v.66, n.3, p.480-490, 1990.

LANORE, D.; DELPRAT, C. Quimioterapia anticancerígena. São Paulo: Roca, 2004. Cap.4, p.53-78.

LUPU, M.; STORB, R. Five decades of progress in haematopoietic stem cell transplantation based on the preclinical canine model. Veterinary and Comparative Oncology, Oxford, v.5, n.1, p.14-30, 2007.

MOORE, A.S. Lymphoma in dogs. In: WORLD CONGRESS OF THE WORLD SMALL ANIMAL VETERINARY ASSOCIATION, 30., 2005, City of Mexico, Mexico. Proceedings... City of Mexico: WSAVA, 2005. Accessed in jun. 04 2007. Online. Available in: http://www.vin.com/ proce eding s / P r o c e eding s.p lx ? C I D = W S AVA $2005 \& \mathrm{PID}=10916 \&$ Category $=1560 \& \mathrm{O}=$ Generic

MORRISON, W.B. Lymphoma in dogs and cats. Jackson Hole, WY: Teton NewMedia, 2004. 124p.

MOULTON, J.E.; HARVEY, J.W. Tumors of the lymphoid and hematopoietic tissues. In: MOULTON, J.E. Tumors in domestic animals. 3.ed. Berkeley: University of California, 1990. 231p.

PATTERSON, K. Bone marrow harvesting. In: TRELEAVEN, J.; WIERNIK, P. Color atlas and text of bone marrow transplantation. London: Mosby-Wolfe, 1993. Cap.3, p.101107.

RODASKI, S.; DE NARDI, A.B. Quimioterapia antineoplásica em cães e gatos. Curitiba: Maio, 2004. 307p.

THOMAS, E.D.; STORB, R. The development of scientific foundation of hematopoietic cell transplantation based on animal and human studies. In: THOMAS, E.D. et al. Hematopoietic cell transplantation. Malden: Blackwell Science, 1999. Cap.1, p.1-11.

VAIL, D.M.; OGILVIE, G.K. Neoplasias linfóides. In: BICHARD, S.J., SHERDING, R.G. Manual Saunders: clínica de pequenos animais. São Paulo: Roca, 1998. p.218-225.

VAIL, D.M.; YOUNG K.M. Canine lymphoma and lymphoid leukemia. In: WITHROW, S.J.; VAIL, D.M. Withrow \& MacEwen's small clinical oncology. St Louis: Saunders, 2007. Cap.31, p.699-732.

VONDERHAAR, M.A.; MORRISON, W.B. Lymphosarcoma. In: MORRISON WB. Cancer in dogs and cats: medical and surgical management. 2.ed. Jackson Hole, WY: Teton NewMedia, 2002. p.641-670. 